\title{
PENGARUH KUALITAS PELAYANAN TERHADAP KEPUASAN KONSUMEN
} (Studi Kasus Pada Konsumen Waroeng Biru Daun Di Kabupaten Situbondo)

\author{
Rachmad Yanuar Fatwa ${ }^{1}$, Sri Wahyuni ${ }^{1}$, Sutrisno Djaja ${ }^{1}$ \\ ${ }^{1}$ Pendidikan Ekonomi, Fakultas Keguruan dan Ilmu Pendidikan, Universitas Jember \\ e-mail: ryans.ry94@gmail.com
}

\begin{abstract}
Abstrak
Seiring dengan pertumbuhan penduduk yang semakin pesat, kebutuhan pendudukpun semakin meningkat, khususnya kebutuhan terhadap makanan. Salah satu alternatif adalah rumah makan atau restoran. Faktor yang dapat meningkatkan kepuasan konsumen salah satunya adalah kualitas pelayanan yang baik. Tujuan penelitian ini yaitu untuk mengetahui pengaruh kualitas pelayanan terhadap kepuasan konsumen pada Konsumen Waroeng Biru Daun di Kabupaten Situbondo. Kualitas pelayanan pada penelitian ini terdiri dari bukti fisik, ketanggapan, kehandalan, jaminan, empati. Sedangkan untuk kepuasan konsumen terdiri dari melakukan pembelian kembali, merekomendasikan kepada orang lain. Penelitian ini merupakan penelitian kuantitatif dengan jumlah 45 reseponden. Uji instrumen dalam penelitian ini adalah uji validitas. Metode analisis data yang digunakan analisis inferensial yang terdiri dari analisis regresi linier sederhana, analisis varian garis regresi, uji F, efektivitas garis regresi, standart eror of estimate. Hasil penelitian menunjukkan bahwa kualitas pelayanan berpengaru terhadap kepuasan konsumen sebesar 67,5\%.
\end{abstract}

Kata Kunci: Kualitas pelayanan, Kepuasan konsumen.

\section{PENDAHULUAN}

Seiring dengan pertumbuhan penduduk yang semakin pesat, kebutuhan pendudukpun semakin meningkat, khususnya kebutuhan terhadap makanan. Salah satu kebutuhan dasar masyarakat agar dapat memenuhi kehidupannya yaitu dengan adanya berbagai macam restoran atau rumah makan yang menyajikan berbagai menu khas dari tempat tersebut. Industri rumah makan di Kabupaten Situbondo Jawa Timur saat ini mengalami pertumbuhan. Pertumbuhan tersebut ditandai dengan semakin bertambahnya jumlah rumah makan disetiap tahunnya. Pertumbuhan ini bentuk respon produsen akan adanya kebutuhan pasar yang terus berkembang. Biasanya pertumbuhan rumah makan dipicu oleh beberapa faktor di antaranya yaitu semakin berkembang minat masyarakat akan makanan cepat saji, pariwisata yang semakin berkembang, semakin meluasnya pendidikan di setiap daerah sehingga membuat perkembangan rumah makan juga ikut naik.

Waroeng Biru Daun adalah sebuah industri yang bergerak dalam bidang kuliner. Lokasinya tidak jauh dari pusat kota Situbondo dan cukup mudah di jangkau. Waroeng Biru Daun terletak di Jalan Melati 102 Curah Jeru Kabupaten Situbondo. Waroeng Biru Daun memiliki konsep berbeda dengan rumah makan lainnya, yaitu konsep lingkup persawahan yang dilengkapi dengan tempat makan berupa gazebo. Waroeng Biru Daun juga menyediakan tempat acara seperti meeting room, memiliki tempat parkir yang cukup luas. Selain itu Waroeng Biru daun juga dilengkapi dengan fasilitas hot spot wifi, live music. Konsep ini memiliki nilai tambah di kalangan masyarakat Situbondo terhadap Waroeng Biru Daun. Salah satu keunikan pelayanan dari Waroeng Biru adalah kentongan di setiap gazebo. Kentongan disini berguna untuk para konsumen jika ingin menambah menu makanan karena tempat makan dan tempat karyawan cukup jauh.

Aspek pelayanan merupakan kunci utama keberhasilan restoran dalam mempertahankan kelangsungan hidup restoran. Untuk itu restoran dituntut agar dapat memberikan pelayanan yang berkualitas yang sesuai dengan dengan kebutuhan konsumen. Menurut Tjiptono (2008:56) kualitas pelayanan merupakan, "sistem manajemen strategik dan integratif yang melibatkan semua manajer dan karyawan serta menggunakan metode-metode kualitatif dan kuantitatif untuk memperbaiki secara berkesinambungan atas proses-proses organisasi, agar dapat memenuhi dan melebihi kebutuhan, dan harapan pelanggan". 
Kualitas pelayanan dapat dilihat dari terpenuhi atau tidak terpenuhinya harapan pelanggan atas pelayanan yang mereka terima. Lupiyoadi (2013:216) menyatakan bahwa "SERVQUAL dibangun atas adanya perbandingan dua faktor utama, yaitu persepsi pelanggan atas layanan yang nyata mereka terima dengan layanan yang sesungguhnya diharapkan". Jika kenyataannya sama atau lebih dari yang diharapkan maka layanan dapat dikatakan berkualitas atau memuaskan. Sebaliknya, jika kenyataan kurang dari yang diharapkan maka layanan dapat dikatakan tidak berkualitas atau tidak memuaskan.

Kualitas pelayanan diwujudkan melalui pemenuhan kebutuhan dan keinginan pelanggan serta ketetapan penyampaiannya dalam mengimbangi atau melampaui harapan pelanggan. Dan menurut Kotler dan Keller (dalam Dimyati 2012:108) kualitas pelayanan harus dimulai dari kebutuhan pelanggan dan berakhir pada persepsi konsumen. Dikaitkan dengan penelitian ini berarti bahwa citra kualitas pelayanan Waroeng Biru Daun berdasarkan sudut pandang atau persepsi konsumen, jika pelayanan yang diterima konsumen sesuai dengan yang diharapkan maka kualitas pelayanan Waroeng Biru Daun dipersepsikan baik atau memuaskan dan sebaliknya.

Menurut Kotler (dalam Tjiptono, 2005:350) kepuasan pelanggan adalah tingkat perasaan dimana seorang menyatakan hasil perbandingan atas kinerja produk atau jasa yang diterima dan diharapkan. Kepuasan konsumen merupakan penilaian yang diberikan atas perbandingan antara harapan konsumen dengan wujud pelayanan yang diberikan restoran. Hal tersebut sesuai dengan pendapat Yazid (2008:55) yang mengatakan kepuasan merupakan perbedaan antara harapan dan kinerja. Apabila harapan tinggi sementara kinerja biasa saja maka kepuasan tidak tercapai, sebaliknya bila kinerja melebihi harapan maka kepuasan meningkat. Kepuasan konsumen dapat terwujud jika konsumen merasakan pelayanan yang diberikan restoran telah sesuai dengan harapan mereka. Sebaliknya konsumen tidak akan merasa puas apabila pelayanan yang diberikan restoran tidak sesuai dengan apa yang mereka harapkan. Kepuasan konsumen bisa dilihat dari konsumen tersebut melakukan pembelian ulang.

Salah satu faktor yang menentukan kepuasan konsumen adalah persepsi pelanggan mengenai kualitas pelayanan yang terdiri dari lima dimensi yaitu bukti fisik, keandalan, daya tanggap, jaminan, empati (Rangkuti, 2002:41). Menurut Kotler (dalam Tjiptono, 2011 : 434) yang menyatakan kepuasan konsumen adalah tingkat perasaan seseorang setelah membandingkan kinerja atau hasil yang dirasakannya dengan harapannya. Terkait dengan kualitas pelayanan Waroeng Biru Daun, apabila Waroeng Biru Daun dapat memberikan kualitas pelayanan yang baik dan sesuai kebutuhan dan harapan konsumennya dalam melayani permintaan konsumen maka konsumen tersebut akan merasa puas, dimana kepuasan konsumen akan memberikan dampak positif pada restaurant dengan merekomendasikan ke orang lain ataupun melakukan pembelian ulang. Sebaliknya jika pelayanan buruk maka konsumen akan merasa tidak puas dan akan beralih pada restaurant lain sehingga dapat memberikan dampak negatif kepada restaurant. Hal tersebut sesuai dengan pendapat Lupiyoadi dan Hamdani (2013 : 196) yang menyatakan bahwa implementasi pelayanan yang baik akan meningkatkan kepuasan pelanggan begitu pula sebaliknya pelayanan yang buruk akan menurunkan kepuasan pelanggan dan tentunya akan berakibat buruk bagi perusahaan. Peneliti tertarik melakukan penelitian untuk mengetahui pengaruh kualitas pelayanan terhadap kepuasan konsumen paada konsumen Waroeng Biru Daun di Kabupaten Situbondo.

\section{METODE}

Metode penelitian ini dilakukan menggunakan metode kuantitatif menggunakan analisis regresi linear sederhana. Adapun metode penentuan lokasi penelitian menggunakan metode purposive area. Penelitian ini dilakukan di restaurant Waroeng Biru Daun Kabupaten Situbondo . Responden penelitian adalah semua pengunjung yang datang berjumlah 45 responden. Metode pengolahan data pada penelitian ini terdiri dari editing, skoring, dan tabulasi. Uji instrumen dalam penelitian ini yaitu uji validitas. Metode analisis data yang digunakan dalam penelitian ini adalah analisis inferensial yang terdiri dari persamaan regresi linier sederhana, analisis varian garis regresi, uji F, efektivitas garis regresi dan standart error of estimate.

\section{HASIL DAN PEMBAHASAN}




\section{Hasil Penelitian}

\section{Persamaan Garis Linier Sederhana}

Hasil analisis regresis linear sederhana dengan menggunakan program SPSS versi 22.0 for windows adalah sebagai berikut :

Tabel 1. Hasil Persamaan Garis Linier Sederhana

\begin{tabular}{lc}
\hline \multicolumn{1}{c}{ Variabel } & Koefisien regresi \\
\hline Kualitas pelayanan $(\mathrm{X})$ & 0,180 \\
\hline Constanta (a) & 1,688 \\
R square & 0,675 \\
Multiple R & 0,821
\end{tabular}

Berdasarkan tabel diatas maka persamaan garis linier sederhana yang diperoleh dalam penelitian ini adalah sebagai berikut:

$$
\mathrm{Y}=1,688+0,180 \mathrm{X}
$$

Adapun hasil perhitungan untuk analisis varian regresi adalah sebagai berikut :

Tabel 2. Hasil analisis varian garis regresi

\begin{tabular}{cc}
\hline Variabel & Multiple $\boldsymbol{R}$ \\
\hline $\begin{array}{c}\text { Kualutas pelayanan (X) terhadap } \\
\text { Kepuasan Konsumen (Y) }\end{array}$ & 0,821 \\
\end{tabular}

Berdasarkan tabel diatas nilai koefisien korelasi sebesar 0,821 tersebut menunjukkan bahwa kualitas pelayanan memiliki hubungan yang sangat kuat terhadap kepuasan konsumen pada konsumen Waroeng Biru Daun Kabupaten Situbondo.

Hasil perhitungan koefisien korelasi $\left(\mathbf{R}_{\text {square }}\right)$ pada penelitian ini adalah sebagai berikut :

$$
\mathrm{R}_{\text {square }} \times 100 \%=0,675 \times 100 \%=67,5 \%
$$

Perolehan tersebut artinya bahwa besaran persentase pengaruh kualitas pelayanan terhadap kepuasan pelanggan pada konsumen Waroeng Biru Daun di Kabupaten Situbondo sebesar 67,5\%. Adapun hasil uji F pada penelitian ini adalah sebagai berikut :

\begin{tabular}{ccccc}
\hline Variabel & $\mathbf{F}_{\text {hitung }}$ & $\mathbf{F}_{\text {tabel }}$ & A & Sig. F \\
\hline $\mathrm{X}, \mathrm{Y}$ & 89,240 & 3,214 & 0,05 & 0,000
\end{tabular}

Berdasarkan tabel diatas diketahui bahwa nilai $F_{\text {hitung }} 89,240$ dengan nilai $F_{\text {tabel }} 3,214$ dan tingkat signifikansi $\mathrm{F}=0,000$, maka nilai $\mathrm{F}_{\text {hitung }}$ yang berjumlah 89,240 lebih besar dari pada $\mathrm{F}_{\text {tabel }}$ yaitu 3,214 dan tingkat signifikansi $0,000<0,05$, sehingga dapat diambil kesimpulan bahwa hipotesis $\mathrm{H} 1$ diterima dan berarti terdapat pengaruh kualitas pelayanan terhadap kepuasan pelanggan pada konsumen Waroeng Biru Daun di Kabupaten Situbondo.

Hasil uji standart error of estimate telah dilakukan oleh peneliti dapat diketahui bahwa nilainya adalah sebesar 0,971 artinya semakin kecil nilai standart error of estimate maka garis tersebut semakin mewakili data aktual.

\section{Pembahasan}

Berdasarkan hasil penelitian yang dilakukan di Waroeng Biru Daun dapat diketahui bahwa kualitas pelayanan yang dimiliki oleh Waroeng Biru Daun berpengaruh terhadap kepuasan konsumen. Hal tersebut ditunjukkan dengan adanya hasil analisis data bahwa kualitas pelayanan berpengaruh terhadap kepuasan konsumen yaitu sebesar $67,5 \%$. Hasil perolehan tersebut mengartikan bahwa 
kualitas pelayanan Waroeng Biru Daun Kabupaten situbondo (yang meliputi bukti fisik, kehandalan, daya tanggap, jaminan, dan empati) cukup memberikan rasa senang kepada para konsumen namun ada juga beberapa konsumen yang mengeluhkan kualitas pelayanan di Waroeng Biru Daun Kabupaten Situbondo.

Salah satu faktor yang dapat meningkatkan kepuasan konsumen yaitu kualitas pelayanan. Kualitas menunjuk pada pengertian pemenuhan standar atau persyaratan tertentu, kualitas juga mempunyai pengertian sebagai upaya untuk melakukan perbaikan dan penyempurnaan secara terusmenerus untuk memenuhi kebutuhan pelanggan sehingga dapat memuaskan pelanggan. Kualitas diartikan sebagai suatu kondisi dinamis dimana yang berhubungan dengan produk, jasa , manusia, proses dan lingkungan yang memenuhi atau melebihi harapan (Tjiptono,2007:51).

Apabila kualitas pelayanan yang diberikan baik maka akan membuat konsumen ingin kembali lagi. kualitas pelayanan yang dimiliki oleh setiap tempat usaha berbeda - beda tergantung oleh kualitas sumber daya manusia itu sendiri. kualitas pelayanan disini dapat dilihat dari bukti fisik, ketanggapan, keandalan, jaminan, empati. kelima indikator tersebut memberikan pengaruh terhadap kepuasan konsumen di Waroeng Biru Daun. kualitas sumber daya manusia dan lingkungan itu dibutuhkan untuk mendukung terciptanya lingkungan kerja dan pelayanan yang baik untuk diberikan kepada konsumen. Hal tersebut sesuai dengan pendapat Lupiyoadi dan Hamdani (2013 : 196) yang menyatakan bahwa implementasi pelayanan yang baik akan meningkatkan kepuasan pelanggan begitu pula sebaliknya pelayanan yang buruk akan menurunkan kepuasan pelanggan dan tentunya akan berakibat buruk bagi perusahaan.

Konsumen yang merasa puas terhadap produk atau jasa yang dikonsumsi atau dipakai akan membeli ulang produk tersebut. Pembelian ulang yang terus menerus dari produk dan jasa yang sama akan menunjukkan kualitas pelayanan yang baik sehingga berdampak pada kepuasan pelanggan. Dengan adanya kualitas pelayanan yang baik, maka minat konsumen untuk datang kembali akan tumbuh begitu saja, begitu juga sebaliknya apabila kualitas pelayanan yang diberikan buruk akan memberikan kesan jelek kepada konsumen yang mengakibatkan konsumen tidak ingin datang kembali.

Bentuk pengaruh antara kualitas pelayanan terhadap kepuasan konsumen adalah pengaruh positif yaitu semakin baik kualitas pelayanan maka semakin tinggi pula kepuasan konsumen. Dengan demikian dapat dijelaskan bahwa jika variabel kualitas pelayanan pada Waroeng Biru Daun di Kabupaten Situbondo meningkat, maka akan diikuti dengan peningkatan kepuasan konsumen dan sebaliknya apabila kualitas pelayanan di Waroeng Biru Daun menurun, maka akan diikuti dengan penurunan kepuasan konsumen.

\section{PENUTUP}

Berdasarkan hasil analisis, maka dapat disimpulkan bahwa terdapat pengaruh yang positif dan signifikan kualitas pelayanan terhadap kepuasan konsumen Waroeng Biru Daun di Kabupaten Situbondo sebesar $67,5 \%$.

Hasil penelitian yang dilakukan semakin tinggi kualitas pelayanan waroeng biru daun maka semakin baik kepuasan konsumen tersebut, sebaliknya semakin rendah kualitas pelayanan maka semakin rendah pula kepuasan konsumen Waroeng Biru Daun. Kepuasan konsumen Waroeng Biru Daun dipengaruhi oleh Bukti fisik, Kehandalan, Ketanggapan, Jaminan, Empati sedangkan kepuasan konsumen waroeng biru daun dipengaruhi oleh Melakukan pembelian kembali, Merekomendasikan layanan kepada orang lain.

Berdasarkan hasil penelitian, maka dapat diberikan saran yaitu sebaiknya waroeng biru daun tetap menjaga kualitas pelayanan sehingga dapat menambah konsumen dan konsumen yang sudah ada tidak berpindah ke tempat lain dengan cara mendengarkan keluhan konsumen dengan ikhlas serta harus memiliki sikap responsif dan tanggap terhadap kebutuhan konsumen.

\section{DAFTAR PUSTAKA}

Dimyati, Mohammad. 2012. Konsep Inti \& Elemen Pemasaran. Mojokerto: Insan Global. Lupiyoadi dan A. Hamdani. 2013. Manajemen Pemasaran Jasa. Jakarta: Salemba Empat. 
Rangkuti, F. 2002. Measuring Costumer Satisfaction.Jakarta: PT Gramedia Pustaka.

Tjiptono, F. 2005. Pemasaran Jasa. Edisi Pertama. Yogyakarta: Penerbit Bayumedia Publishing.

Tjiptono, F., Chandra., Andriani, G., dan Dadi. 2008. Pemasaran Strategik.Yogyakarta: C.V Andi Offset.

Tjiptono, F. dan Chandra. 2011. Service Quality and Satisfaction. Yogyakarta: C.V Andi Offset.

Yazid. 2008. Pemasaran Jasa. Edisi Kedua. Yogyakarta: Ekonisia Kampus Fakultas Ekonomi UII. 